\title{
PENGARUH KUALITAS PRODUK DAN CITRA MEREK TERHADAP KEPUASAN KONSUMEN PRODUK KAOS MEREK JAKOZ (THE EFFECT OF PRODUCT QUALITY AND BRAND IMAGE ON CONSUMER SATISFACTION OF JAKOZ BRAND T-SHIRT PRODUCT)
}

\author{
Erida $^{1}$, Sigit Indrawijaya ${ }^{2}$, Deldi Abdilah ${ }^{3}$ \\ ${ }^{1,2,3)}$ Prodi Manajemen Fakultas Ekonomi dan Bisnis Universitas Jambi \\ Email: deldiabdilah97@gmail.com
}

\begin{abstract}
Abstrak
Penelitian ini bertujuan menganalisis pengaruh kualitas produk (X1) dan citra merek (X2) terhadap kepuasan konsumen $(Y)$ baik secara persial maupun simultan pada produk kaos merek Jakoz. Penelitian ini adalah penelitian survey. dengan jumlah sampel yang diambil sebanyak 120 responden. Instrumen penelitian menggunakan kuisioner dan dianalisis menggunakan persamaan regresi linear berganda. Berdasarkan hasil analisis membuktikan bahwa kepuasan konsumen dipengaruhi oleh citra merek dan kualitas produk, namun demikian terdapat juga faktor lain yang mempengaruhi kepuasan konsumen selain kualitas produk dan citra merek yang perlu dilanjuti oleh penelitian lain untuk meningkatkan kepuasan konsumen dari perspektif yang berbeda.
\end{abstract}

Kata Kunci: Kualitas Produk, Citra Merek dan Kepuasan Konsumen.

\begin{abstract}
This study aims to analyze the influence of product quality $(X 1)$ and brand image $(X 2)$ on consumer satisfaction $(Y)$ both persially and simultaneously on Jakoz branded $T$ shirt products. The number of samples taken was 120 respondents. This research is a survey research. Research instruments using questionnaires and analyzed using multiple linear regression equations. Based on the results of the analysis prove that consumer satisfaction is influenced by brand image and product quality, however there are also other factors that influence consumer satisfaction besides product quality and brand image that need to be followed up by other studies to improve consumer satisfaction from different perspectives.
\end{abstract}

Keywords: Product Quality, Brand Image and Consumer Satisfaction.

\section{PENDAHULUAN}

Pada era globalisasi, persaingan bisnis yang dihadapi perusahaan-perusahaan pada saat ini semakin ketat, sehingga menuntut manajemen lebih cermat dalam menentukan strategi bersaingnya agar dapat memenangkan persaingan yang dihadapi. Pasar semakin berorientasi pada keinginan pelanggan yang semakin bervariasi. Maka seluruh perusahaan akan bersaing untuk memenuhi permintaan konsumen tersebut. Hal ini akan mengakibatkan semakin banyaknya ragam produk yang beredar di pasar dan akan mengakibatkan semakin banyaknya selektifnya konsumen dalam memilih dan mempergunakan barang- barang yang ditawarkan produsen sesuai dengan keinginan dan kebutuhannya. 
Pelanggan adalah darah kehidupan setiap organisasi, dan tanpa pelanggan tidak ada organisasi yang mampu mempertahankan keberadaannya. Pelanggan akan bertahan dengan suatu produk jika kosumen merasa puas dengan produk tersebut. Kualitas merupakan hal yang paling mendasar dari kepuasan konsumen dan kesuksesan dalam bersaing. Dalam jangka panjang, ikatan ini memungkinkan perusahaan untuk memahami harapan dan kebutuhan konsumen. Kepuasan konsumen pada akhirnya akan menciptakan loyalitas pelanggan kepada perusahaan yang memberikan kualitas yang memuaskan mereka. Kepuasan atau ketidakpuasan konsumen merupakan hasil dari adanya perbedaan antara harapan konsumen dengan kinerja yang dirasakan oleh konsumen tersebut (Dedy Londong, 2012).

Kepuasan konsumen juga didasari dengan merek produk tersebut. Merek merupakan simbol atau tanda yang membantu bagi pelanggan untuk mengidentifikasi produk, perusahaan yang memiliki produk dengan brand image yang menguntungkan oleh masyarakat pasti yang diperoleh posisi yang lebih baik. Selain itu, merek merupakan identitas untuk membedakan identitas produk perusahaan dengan produk yang dihasilkan oleh pesaing. Merek juga dapat membantu perusahaan untuk memperluas lini produk serta mengembangkan posisi pasar yang spesifik bagi suatu produk. Citra merek yaitu deskripsi tentang asosiasi dan keyakinan konsumen terhadap merek tertentu (Tjiptono, 2008).

Semakin kuat Brand image dibenak pelanggan maka semakin kuat pula rasa percaya diri pelanggan untuk tetap setia terhadap produk yang dibelinya sehingga hal tersebut dapat mengantar sebuah perusahaan untuk tetap mendapatkan keuntungan dari waktu ke waktu. Persaingan semakin meningkat diantara merek-merek yang beroperasi dipasar. Hanya produk yang memiliki citra merek yang kuat yang tetap mampu bersaing dan mampu menguasai pasar (MC. Maryati, 2014). Merek merupakan simbol atau tanda yang membantu bagi pelanggan untuk mengidentifikasi produk (Satendra Thakur, 2012).

Persaingan usaha fashion di daerah Jambi juga mulai menjamur beberapa tahun belakangan ini, hal itu bisa dilihat dengan semakin menjamurnya distro-distro atau toko-toko yang menjual berbagai macam produk kaos dan produk fashion lainnya. Gerai Souvenir Jakoz merupakan perusahaan yang bergerak di bidang oleh-oleh khas Jambi, yaitu sebagai produsen kaos yang berbumbu Jambi. Toko Souvenir yang tengah naik daun di daerah Jambi yaitu Jakoz, dimana produk-produk mereka menonjolkan produk-produk yang memiliki ciri khas daerah Jambi.

Pembahasan tersebut, dapat dijelaskan bahwa Citra merek sangat berpengaruh terhadap kepuasan konsumen. Bukan hanya citra merek, tetapi kualitas produk juga mempengaruhi kepuasan konsumen. Kualitas dipahami sebagai faktor pendukung kepuasan konsumen. Kualitas merupakan totalitas fitur dan karakteristik produk atau jasa yang mengandalkan kemampuannya untuk menciptakan kepuasan. Produk dengan kualitas yang baik tentunya akan memberikan rasa puas didalam benak konsumen. Konsumen akan merasa puas jika produk yang dibelinya memiliki kualitas yang baik sesuai dengan yang diharapkan konsumen. Berdasarkan uraian diatas menunjukan bahwa brand image (citra merek) dan kualitas produk adalah faktor penting dalam membangun kepuasan konsumen.

Dalam pesatnya perkembangan dunia usaha saat ini memicu berkembanganya bisnis di dunia pakaian. Bisnis di dunia tersebut seakan tidak pernah mati karena pakaian selalu berkembang dan mengikuti perkembangan zaman. Hal itu lah yang harus dilakukan oleh gerai Jakoz Beyik untuk mempertahankan kualitas produk dan citra 
merek untuk membuat konsumen puas dan menjadi loyal atau setia dengan produk tersebut.Berdasarkan latar belakang yang telah diuraikan, maka diketahui permasalahan yang diangkat dari penelitian ini adalah Bagaimana pengaruh kualitas produk dan citra merek terhadap kepuasan konsumen produk kaos merek Jakoz?.

\section{TINJAUAN PUSTAKA}

Menurut Kotler dan Amstrong (2008) produk adalah suatu sifat yang kompleks dapat diraba, termasuk bungkus, warna, harga prestasi perusahaan dan pengecer yang diterima oleh pembeli untuk memuaskan kebutuhan dan keinginan. Lebih lanjut Kotler dan Amstrong (2008) mengemukakan konsumen akan menyukai produk yang menawarkan kualitas, kinerja, dan fitur yang paling baik, oleh karena itu organisasi atau perusahaan harus memberikan kemampuannya untuk membuat perbaikan produk berkelanjutan.

Pada saat ini Kualitas produk merupakan faktor penting yang mempengaruhi kinerja jangka panjang suatu unit bisnis. Menurut Tjiptono (2008) bahwa kualitas mencermikan semua dimensi penawaran produk yang menghasilkan manfaat (benefit) bagi pelanggan. Kualitas suatu produk baik berupa barang atau jasa ditentukan melalui dimensi-dimensinya. Kualitas produk yang dapat diterima adalah elemen utama yang mempengaruhi perilaku pembelian konsumen (Sigit Indrawijaya, 2014).

Menurut Kotler dan Armstrong (2012) merupakan kemampuan sebuah produk dalam memperagakan fungsinya, hal ini termasuk keseluruhan durabilitas, reliabilitas, ketepatan, kemudahan pengoperasian, dan reparasi produk, juga atribut produk lainnya.Selanjutnya menurut Tjiptono (2008) berpendapat bahwa citra merek adalah sekumpulan keyakinan, ide, kesan dan persepsi dari seseorang, suatu komunitas, atau masyarakat tentang suatu merek. Citra merek (brand image) juga merupakan deskripsi tentang asosiasi dan keyakinan konsumen tentang merek tertentu, sedangkan asosiasi merupakan atribut yang ada didalam merek dan memililki suatu tingkat kekuatan.

Kotler dalam Buchari Alma (2018) menjelaskan bahwa "image is the set of beliefs, ideas and impressions that a person holds regarding an object. People's attitude and actions towards an object are highly conditional by that objet's image. Citra adalah sebuah seperangkat keyakinan, ide dan kesan bahwa seseorang memegang kepercayaan kepada sesuatu objek (merek), sikap seseorang dan tindakan berkelanjutan terhadap objek ditentukan kondisi yang tinggi oleh citra objek (merek) tersebut.

Pada saat ini kepuasan konsumen merupakan perasaan seseorang akan kesenangan atau kekecewaan yang dihasilkan dari membandingkan kinerja produk yang dirasakan (atau hasil) dengan harapan mereka (Kotler dan Keller, 2012). Menurut Anung Pramudyo (2012) bila kepuasan konsumen dapat tercipta dengan baik, ini merupakan keberhasilan yang dicapai oleh perusahaan. Cara memuaskan konsumen, perusahaan dapat meningkatkan keuntungannya dan mendapat pangsa pasar yang lebih luas, karena bagi perusahaan, salah satu faktor penentu kesuksesan dalam menciptakan loyalitas para pelanggannya adalah menciptakan kepuasan.

Dari Penjelasan diatas, hipotesis penelitian ini adalah kualitas produk dan citra merek berpengaruh positif dan signifikan terhadap kepuasan konsumen produk kaos merek Jakoz. 


\section{Kerangka Pemikiran}

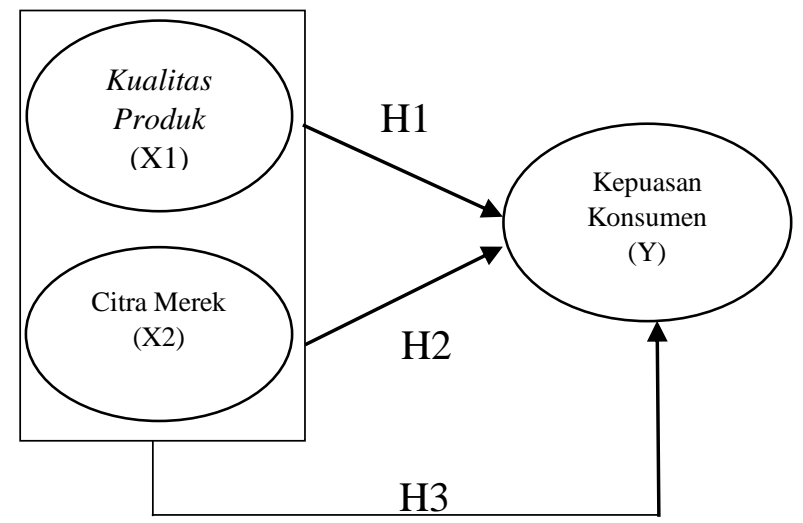

\section{METODE PENELITIAN}

\section{Populasi dan Sampel}

Populasi pada penelitian ini adalah seluruh konsumen yang pernah membeli produk kaos merek Jakoz. Sampel diambil dengan menggunakan teknik Purposive sampling, merupakan metode pemilihan sampel berdasarkan pertimbangan tertentu. Pada penelitian ini menggunakan rumus Slovin karena menurut rumus ini dalam penarikan sampel, jumlah harus representatif (mewakili) agar hasil penelitian dapat digeneralisasikan. Jumlah sampel yang menjadi responden dalam penelitian sebanyak 120 responden.

\section{Metode dan Alat Analisis Data}

Dalam penelitian ini adalah menggunakan metode desktiptif. Analisis statistik deskriptif digunakan untuk menganalisis data dengan cara mendiskripsikan atau memberikan gambaran terhadap objek yang diteliti melalui data sampel/populasi sebagaimana adanya tanpa bermaksud membuat kesimpulan yang berlaku untuk umum atau generalisasi. Selanjutnya dalam penelitian ini menggunakan analisis Regresi Linier Berganda. Analisis linier berganda merupakan analisis perluasan dari regresi linier sederhana, yaitu menambah jumlah variabel bebas yang sebelum hanya satu menjadi dua atau lebih variabel bebas.

\section{Variabel Penelitian}

Variabel independen dalam penelitian ini adalah Kualitas Produk (X1), Citra Merek sebagai (X2), dan variabel dependennya adalah Kepuasan Konsumen (Y), variabel dependen merupakan variabel yang dipengaruhi atau menjadi akibat karena adanya variabel bebas atau disebut variabel terikat.

\section{HASIL DAN PEMBAHASAN}

\section{Karakteristik Responden}

Profil responden dalam penelitian ini dibedakan berdasarkan Usia, jenis kelamin, pekerjaan, berdasarkan pengalaman berapa kali membeli produk kaos merek Jakoz dalam waktu lima tahun terakhir dan alasan memilih produk kaos merek Jakoz.

Berdasarkan usia responden yang paling dominan adalah pada rentang usia 2030 tahun sebanyak 53 orang. Berdasarkan jenis kelamin paling dominan adalah Lakilaki dengan total sebanyak 76 orang. Berdasarkan pekerjaan yang paling dominan adalah mahasiswa/i sebanyak 39 orang. Berdasarkan pengalaman berapa kali membeli 
produk kaos merek Jakoz dalam waktu lima tahun terakhir dari 6-10 kali sabanyak jumlah sampel yaitu 52 orang responden. Berdasarkan alasan memilih produk kaos merek Jakoz yang paling dominan adalah desain produk sebanyak 49 orang.

\section{Deskripsi hasil Tanggapan Responden}

Penilaian responden berdasarkan variabel kualitas produk yang terdiri dari 14 item pernyataan dengan nilai rata-rata 4,27 dan berkategori positif. Pada variabel citra merek terdiri 10 pernyataan dengan nilai rata-rata 4,2 dan berkategori positif. Selanjutnya pada variabel kepuasan konsumen terdiri dari 6 pernyataan dan memiliki rata-rata 4,26 yang berkategori positif.

\section{Uji Validitas dan Reabilitas}

Berdasarkan uji validitas adalah setiap pernyataan menghasilkan korelasi yang lebih besar dari $\mathrm{R}$ tabel $(0,1793)$. Sehingga dapat disimpulkan bahwa setiap pernyataan pada variabel adalah valid. Berdasarkan uji reabilitas adalah semua hasil pengukuran setiap variable menghasilkan nilai Cronbach Alpha diatas 0,6. Sehingga dapat disimpulkan bahwa setiap variabel dari koesioner adalah reliabel.

\section{Uji Asumsi Klasik}

1. Uji Normalitas

Pengujian normalitas ini dilakukan dengan metode grafik Normal Probability plot (P-plot) yang dapat dilihat pada gambar berikut ini :

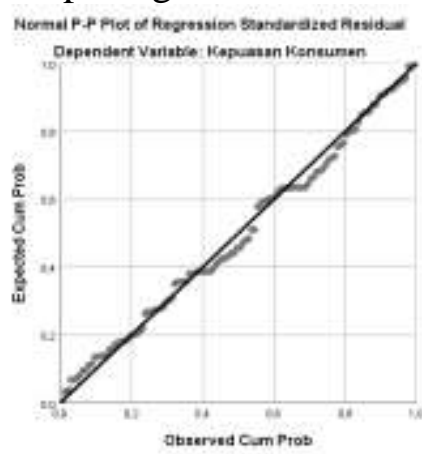

Berdasarkan pada gambar 5.3.1 pada gambar normal probability plot dapat kita lihat pela titik-titik plot tersebar berhimpitan disekitar garis diagonal yang ada dan mengikuti garis diagonal. Maka dapat disimpulkan bahwa nilai residual dari data terdistribusi normal atau memenuhi uji asumsi klasik.

2.Uji Multikolinearitas

\begin{tabular}{|c|c|c|c|c|c|c|c|c|}
\hline \multicolumn{9}{|c|}{ Coefficients $^{\mathbf{a}}$} \\
\hline & \multirow[t]{2}{*}{ Model } & \multicolumn{2}{|c|}{$\begin{array}{l}\text { Unstandardized } \\
\text { Coefficients }\end{array}$} & \multirow{2}{*}{$\begin{array}{c}\text { Standardized } \\
\text { Coefficients } \\
\text { Beta }\end{array}$} & \multirow[t]{2}{*}{$\mathrm{T}$} & \multirow[t]{2}{*}{ Sig. } & \multicolumn{2}{|c|}{$\begin{array}{l}\text { Collinearity } \\
\text { Statistics }\end{array}$} \\
\hline & & B & Std. Error & & & & Tolerance & VIF \\
\hline \multirow{3}{*}{1} & (Constant) & 4,381 & 1,539 & & 2,846 & 0,005 & & \\
\hline & Kualitas Produk & 0,121 & 0,035 & 0,294 & 3,432 & 0,001 & 0,441 & 2,269 \\
\hline & Citra Merek & 0,333 & 0,052 & 0,544 & 6,345 & 0,000 & 0,441 & 2,269 \\
\hline
\end{tabular}

Sumber : Hasil pengolahan data SPSS versi 25, 2019 
Dari tabel 5.14 dapat kita lihat bahwa semua variabel nilai VIF yang lebih kecil dari 10 dan nilai Tolerance yang lebih besar dari 0,10 yang mengartikan tidak terdapat korelasi antar variabel independent atau dapat disimpulkan bahwa tidak terdapat multikolinearitas antar variabel independent di dalam model regresi.

3, Uji Heteroskedastisitas

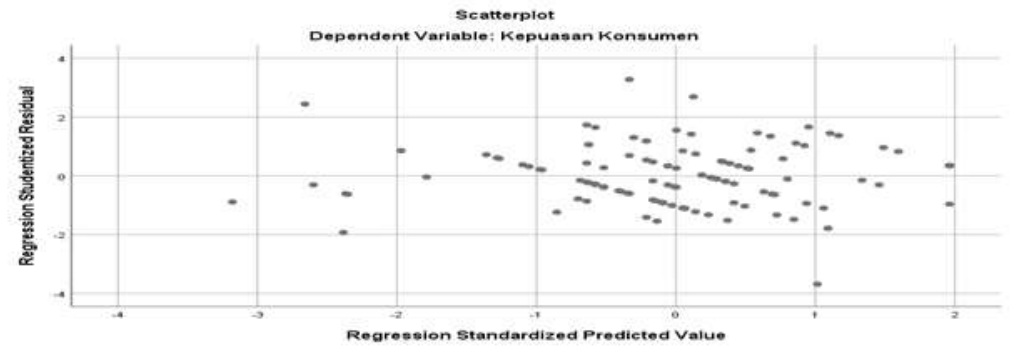

Pada gambar 5.2 dapat dilihat bahwa titik-titik pada scatterlot tidak membentuk pola tertentu dan menyebar di atas maupun dibawah angka 0 pada sumbu Y yang mengartikan tidak terjadi heteroskedastisitas pada hasil uji ini.

\section{Uji Regrsi Linier Berganda}

Berdasarkan hasil analisis dengan menggunakan program SPSS versi 25 , diperoleh hasil analisis regresi linier berganda sebagai berikut:

$$
\mathrm{Y}=\mathrm{a}+b_{1} \cdot X_{1}+b_{2} \cdot X_{2}+\mathrm{e}
$$

\begin{tabular}{|c|c|c|c|c|c|c|}
\hline \multicolumn{7}{|c|}{ Coefficients $^{a}$} \\
\hline & & \multicolumn{2}{|c|}{$\begin{array}{l}\text { Unstandardized } \\
\text { Coefficients }\end{array}$} & \multirow{2}{*}{$\begin{array}{c}\text { Standardized } \\
\text { Coefficients } \\
\text { Beta }\end{array}$} & \multirow[b]{2}{*}{$\mathrm{t}$} & \multirow[b]{2}{*}{ Sig. } \\
\hline \multicolumn{2}{|c|}{ Model } & $\mathrm{B}$ & Std. Error & & & \\
\hline \multirow[t]{3}{*}{1} & (Constant) & 4,381 & 1,539 & & 2,846 & 0,005 \\
\hline & Kualitas Produk & 0,121 & 0,035 & 0,294 & 3,432 & 0,001 \\
\hline & Citra Merek & 0,333 & 0,052 & 0,544 & 6,345 & 0,000 \\
\hline
\end{tabular}

Sumber: Hasil pengolahan data SPSS versi 25, 2019

$$
\mathrm{Y}=4,381+0,121 \cdot X_{1}+0,333 \cdot X_{2}
$$

1. Nilai Konstanta $=4,381$

Ini berarti juga semua variabel independent (kualitas produk dan citra merek) dianggap saam dengan nol (0) maka nilai variabel dependen (kepuasan konsumen) sebesar 4,381.

2. Kualitas Produk $\left(\mathrm{X}_{1}\right)=0,121$

Nilai koefisien kualitas produk bertanda positif terhadap kepuasan konsumen dengan nilai koefisien regresi sebesar 0,121 . Hal ini menunjukkan bahwa setiap nilai variabel kualitas produk satu poin/satuan sementara variabel kualitas produk diasumsikan tetap, maka variabel kepuasan konsumen (Y) akan meningkat sebesar 0,121 .

3. Citra Merek $\left(\mathrm{X}_{2}\right)=0,333$

Nilai koefisien citra merek bertanda positif terhadap kepuasan konsumen dengan nilai koefisien regresi sebesar 0,333 . Hal ini menunjukkan bahwa setiap 
nilai variabel citra merek dinaikkan satu poin/satuan sementara variabel citra merek diasumsikan tetap, maka variabel kepuasan konsumen (Y) akan meningkat 0,333 .

\section{Uji Hipotesis (Uji t / Parsial)}

Pengujian ini bertujuan untuk menguji apakah masing-masing variabel independen dalam model berpengaruh secara signifikan terhadap variabel dependent.

\begin{tabular}{|c|c|c|c|c|c|c|}
\hline \multicolumn{7}{|c|}{ Coefficients $^{\mathrm{a}}$} \\
\hline & & \multicolumn{2}{|c|}{$\begin{array}{l}\text { Unstandardized } \\
\text { Coefficients }\end{array}$} & \multirow{2}{*}{$\begin{array}{c}\text { Standardized } \\
\text { Coefficients } \\
\text { Beta }\end{array}$} & \multirow[b]{2}{*}{$t$} & \multirow[b]{2}{*}{ Sig. } \\
\hline \multicolumn{2}{|c|}{ Model } & $\mathrm{B}$ & Std. Error & & & \\
\hline \multirow[t]{3}{*}{1} & (Constant) & 4,381 & 1,539 & & 2,846 & ,005 \\
\hline & Kualitas Produk & ,121 & ,035 & ,294 & 3,432 &, 001 \\
\hline & Citra Merek & ,333 & ,052 &, 544 & 6,345 &, 000 \\
\hline
\end{tabular}

Sumber: Hasil pengolahan data SPSS versi 25

\section{1) Uji t Kualitas Produk $\left(X_{1}\right)$ Terhadap Kepuasan Konsumen (Y)}

Dari hasil uji regresi pada tabel 5.17 diatas dengan menggunakan SPSS versi 25 diperoleh nilai signifikansi sebesar 0,001 dikarenakan angka taraf signifikansi $<0,05(0,001<0,05)$ maka dapat disimpulakan bahwa kualitas produk $\left(\mathrm{X}_{1}\right)$ berpengaruh terhadap kepuasan konsumen $(\mathrm{Y})$. Artinya terdapat hubungan linier antara kualitas produk $\left(\mathrm{X}_{1}\right)$ dengan kepuasan konsumen $(\mathrm{Y})$.

\section{2) Uji t Citra Merek $\left(X_{2}\right)$ Terhadap Kepuasan Konsumen $(Y)$}

Dari hasil uji regresi pada tabel 5.17 diatas dengan menggunakan SPSS versi 25 diperoleh nilai signifikansi sebesar 0,000 dikarenakan angka taraf signifikansi $<0,05(0,000<0,05)$ maka dapat disimpulkan bahwa citra merek $\left(\mathrm{X}_{2}\right)$ berpengaruh terhadap kepuasan konsumen (Y). Artinya terdapat hubungan linier antara citra merek $\left(\mathrm{X}_{2}\right)$ dengan kepuasan konsumen $(\mathrm{Y})$.

\section{Uji f (uji simultan)}

Pengujian ini bertujuan untuk mengetahui apakah variabel independent yaitu faktor kualitas produk dan citra merek dalam model secara bersama-sama berpengaruh terhadap kepuasan konsumen.

\begin{tabular}{|c|c|c|c|c|c|c|}
\hline \multicolumn{7}{|c|}{ ANOVA } \\
\hline \multicolumn{2}{|c|}{ Model } & Sum of Squares & Df & Mean Square & $\mathrm{F}$ & Sig. \\
\hline \multirow[t]{3}{*}{1} & Regression & 464,146 & 2 & 232,073 & 95,998 &, $000^{b}$ \\
\hline & Residual & 282,846 & 117 & 2,417 & & \\
\hline & Total & 746,992 & 119 & & & \\
\hline
\end{tabular}

Sumber: Hasil pengolahan data SPSS versi 25, 2019

Dari uji Anova atau F test dengan menggunakan SPSS 25 terlihat bahwa nilai $F_{\text {hitung }}$ sebesar 95,998 dengan p-value sebesar 0,000, dikarenakan angka taraf 
signifikansi jauh lebih $<\alpha=0,05$. Dengan demikian $H_{3}$ terima dari hasil tersebut dapat dinyatakan bahwa secara simultan kualitas produk dan citra merek berpengaruh terhadap kepuasan konsumen prodiuk kaos merek Jakoz.

\section{Uji Koefisien Determinasi $\left(R^{2}\right)$}

\section{Model Summary}

\begin{tabular}{|c|c|c|c|c|}
\hline Model & $\mathrm{R}$ & $\mathrm{R}$ Square & Adjusted R Square & $\begin{array}{c}\text { Std. Error of the } \\
\text { Estimate }\end{array}$ \\
\hline 1 &, $788^{\mathrm{a}}$ &, 621 &, 615 & 1,55483 \\
\hline \multicolumn{2}{|c|}{ a. Predictors: (Constant), Citra Merek, Kualitas Produk } \\
\hline
\end{tabular}

Sumber: Hasil pengolahan data SPSS versi 25, 2019

Berdasarkan pada tabel 5.16 diatas, maka dapat dilihat bahwa nilai koefisien determinasi yang diperoleh dari penelitian ini sebesar 0,621 atau 62,1\%. Hal ini menunjukkan bahwa kualitas produk dan citra merek berpengaruh $62,1 \%$ terhadap kepuasan konsumen. Sedangkan sisanya dipengaruhi oleh variable lain yang tidak terdapat pada penelitian ini.

\section{HASIL DAN PEMBAHASAN}

Penelitian ini menganalisis tentang pengaruh kualitas produk dan citra merek terhadap kepuasan konsumen produk kaos merek Jakoz dengan jumlah sampel sebanyak 120 responden dan 30 pertanyaan.

\section{Pengaruh Kualitas Produk Terhadap Kepuasan Konsumen}

Berdasarkan pengujian hipotesis yang dilakukan dengan menggunakan uji persial (uji t) seperti yang terlihat pada tabel diperoleh nilai signifikansi lebih kecil dari $5 \%$, sehingga dapat disimpulkan bahwa kualitas produk $\left(\mathrm{X}_{1}\right)$ berpengaruh terhadap kepuasan konsumen (Y). Hal ini dapat diartikan bahwa semakin baik kualitas produk kaos merek Jakoz maka akan semakin meningkat kepuasan konsumennya. Sebaliknya jika kualitas produk yang diberikan dirasa tidak sesuai atau tidak baik, maka akan berdampak terhadap menurunnya kepuasan konsumen.

dari hasil survey yang dilakukan diketahui bahwa responden memberikan persepsi yang baik terhadap kualitas produk kaos merek Jakoz. Dimana sebagian besar responden menyatakan setuju atas pertanyaan yang diajukan. Yang menjelaskan bahwa responden setuju jika kualitas produk kaos merek Jakoz dinilai memiliki kualitas yang baik oleh responden. Baik itu dari tampilannya, fitur, konformasi, daya tahan, estetika, kehandalan maupun kualitas yang dirasakan oleh responden

Kualitas produk merupakan salah satu cara untuk memenangkan persaingan di pasar. Kualitas produk dapat menciptakan suatu keunggulan bersaing pada suatu badan usaha. Setiap orang memiliki cara pandang dan standar yang berbeda didalam menilai barang atau jasa yang ditawarkan. Oleh karena itu dalam mengelola kualitas produk suatu produk harus sesuai dengan kegunaan yang diinginkan konsumen.

Kualitas mempunyai dampak langsung pada kinerja produk dan jasa, kualitas berhubungan erat dengan nilai dan kepuasan konsumen. Kualitas produk yang baik pada dasarnya akan memberikan pengaruh positif terhadap perusahaan, karena konsumen akan memilih produk dengan kualitas yang terbaik. Kemampuan produk dalam memberikan kualitas terbaik akan menguatkan kedudukan atau posisi produk 
dalam benak konsumen pada pembeli diwaktu yang akan datang. Kualitas yang baik memungkinkan adanya kepuasan konsumen dan akan menarik konsumen baru.

\section{Pengaruh Citra Merek Terhadap Kepuasan Konsumen}

Berdasarkan pengujian hipotesis yang dilakukan dengan menggunakan uji persial (uji t) seperti yang terlihat pada tabel 5.17 diperoleh nilai yang signifikansi lebih kecil dari 5\% sehingga dapat disimpulkan bahwa citra merek $\left(\mathrm{X}_{2}\right)$ berpengaruh terhadap kepuasan konsumen (Y). Hal ini dapat diartikan bahwa semakin baik citra meerek kaos merek Jakoz maka akan semakin meningkat kepuasan konsumennya. Sebaliknya jika citra merek yang diberikan tidak sesuai atau tidak baik, maka akan berdampak terhadap menurunnya kepuasan konsumen.

Dari hasil survey yang dilakukan diketahui bahwa responden memberikan persepsi yang baik terhadap citra merek kaos merek Jakoz. Dimana sebagian besar responden menyatakan setuju atas pertanyaan yang diajukan. Yang menjelaskan bahwasanya konsumen setuju jika kaos merek Jakoz memiliki citra yang baik dipersepsi responden. Baik itu dari atribut, nilai, budaya, kepribadian dan pemakai. Sehingga mampu memberikan rasa puas bagi konsumen sebagai pengguna, dan rasa puas itu ditunjukan terhadap kepuasannya konsumen dalam menggunakan kaos merek Jakoz

Citra merupakan sebagai sebuah gambaran yang ada di dalam benak seorang individu. Citra terdapat suatu poduk tidak dapat dipisahkan dari merek produk tersebut dan juga perusahaan yang mengeluarkan produk merek tersebut ke dalam pasar. Citra merek merupakan serangkaian asosiasi (persepsi) yang ada dalam benak konsumen terhadap suatu merek, biasanya terorganisasi menjadi suatu makna

Hubungan terhadap suatu merek akan semakin kuat jika didasarkan pada pengalaman dan mendapat banyak informasi. Citra atau asosiasi merepresentasikan persepsi yang bisa merefleksikan kenyataan yang objektif ataupun tidak. Citra yang terbentuk dari asosiasi (persepsi) inilah yang mendasari keputusan membeli bahkan loyalitas merek (brand loyality) dari konsumen. Citra merek meliputi pengetahuan dan kepercayaan akan atribut merek (aspek kognitif), konsekuensi dari penggunaan merek tersebut dan situasi penggunaan yang sesuai, begitu juga dengan evaluasi, perasaan dan emosi yang dipresepsikan dengan merek tersebut (aspek afektif).

Merek dapat membantu perusahaan untuk memperluas lini produk serta mengembangkan posisi pasar yang spesifik bagi suatu produk. Semakin kuat citra merek dibenak konsumen maka semakin kuat pula rasa percaya diri pelanggan terhadap produk yang dibelinya sehingga hal tersebut dapat mengantar sebuah perusahaan untuk tetap mendapatkan keuntungan dari waktu ke waktu.

\section{3. pengaruh simultan}

Dari hasil pengujian yang dilakukan secara simultan dengan menggunakan uji $\mathrm{f}$ diketahui bahwa kualitas produk dan citra merek memiliki pengaruh terhadap kepuasan konsumen. Hal ini dibuktikan melalui hasil uji Anova atau atau uji $\mathrm{f}$ test dengan menggunakan SPSS versi 25 didapat angka taraf signifikansi jauh lebig $<0,05(0,000<$ 0,05), sehingga dapat disimpulkan bahwa hipotesis nol $\left(\mathrm{H}_{0}\right)$ ditolak dan hipotesis alternatif $\left(\mathrm{H}_{1}\right)$ diterima artinya hal ini membuktikan variabel kualitas produk dan citra merek secara bersama-sama berpengaruh secara signifikanterhadap variabel kepuasan konsumen produk kaos merek Jakoz. Dimana besarnya kualitas produk dan citra merek 
terhadap kepuasan konsumen sebesar $62,1 \%$, sedangkan sisanya sebesar $37,9 \%$ dipengaruhi oleh variabel lain yang tidak dimasukan dalam model ini.

Berdasarkan hasil survey yang dilakukan responden memberikan persepsi yang baik terhadap variabel kepuasan konsumen, dimana variabel kepuasan konsumen termasuk kriteria sangat puas. Kepuasan merupakan asset yang sangat berharga bagi perusahaan karena dengan menjadi pelanggan yang loyal mereka memiliki komitmen terhadap merek yang kemudian akan mendatangkan profit bagi perusahaan. Konsumen yang puas salah satunya adalah dengan terus melakukan pembelian ulang terhadap suatu produk yang dikeluarkan oleh perusahaan. Selain itu konsumen yang puas juga akan lebih memilih produk yang mereka sukai ketimbang produk lainnya.

Kepuasan pada dasarnya tidak muncul begitu saja, perusahaan haruslah mampu mengatur strategi bagaimana mengelola atau mempertahankan konsumen dengan cara mengenal dan mengetahui apa yang menjadi kebutuhan dari konsumen dengan harapan konsumen tersebut ingin membeli produk yang ditawarkan. Untuk mencapai kepuasan konsumen tentu terdapat banyak cara yang dapat dilakukan oleh perusahaan. Salah satu cara yang efektif untuk dapat mencaapi kepuasan konsumen adalah dengan memberikan kualitas produk yang baik.

\section{SIMPULAN DAN SARAN}

\section{Kesimpulan}

Berdasarkan hasil penelitian dan pembahasan pengaruh kualitas produk dan citra meek tehadap kepuasan konsumen produk kaos merek Jakoz, maka dapat ditarik kesimpulan sebagai berikut :

1. Ada pengaruh signifikan kualitas produk terhadap kepuasan konsumen.

2. Ada pengaruh signifikan citra merek terhadap kepuasan konsumen.

3. Ada pengaruh signifikan kualitas produk dan citra merek secara simultan atau bersama-sama terhadap kepuasan konsumen.

\section{Saran}

Saran berdasarkan hasil analisis dan pembahasan pada bab sebelumnya dapat diberikan saran sebagai berikut :

1. Kedepan hendaknya manajemen mempertimbangkan kualitas produk serta ragam jenis sesuai dengan jenis budaya dan objek wisata, serta selogan kalimat jambi sehingga konsumen akan mendapatkan banyak pilihan model sablon kaos yang menarik dengan kualitas yang bagus. Hal ini akan menjadikan produk kaos merek Jakoz tampak beragam pilihan dan memberikan kesan yang berkualitas.

2. Kedepan diharapkan gerai Jakoz Beyik dapat terus mengembangkan produk kaosnya sehingga memiliki keunggulan dalam setiap aspeknya sehingga menciptakan citra merek yang lebih kuat mengingat persaingan produk kaos sekarang ini semakin banyak.

3. Penelitian yang akan datang di sarankan untuk mencari variabel moderating yang memperkuat variabel kepuasan pelanggan . Karena dalam penelitian ini belum memasukan variabel moderating atas aspek lain yang lebih banyak agar mendapat hasil yang lebih akurat. 


\section{DAFTAR PUSTAKA}

Alma, B. (2018). Manajemen Pemasaran dan Pemasaran Jasa. Cetakan Ketiga belas. Bandung: Alfabeta.

Indrawijaya, Sigit. (2014). Pengaruh Kualitas Produk dan Word of Mouth Terhadap Keputusan Konsumen Dalam Pembelian Roti Manis Pada Industri Kecil di Kabupaten Sarolangun. journal.unja.ac.id. Mankeu. Vol. 1, No. 3.

Kotler, P dan Armstrong, G. (2008). Prinsip-prinsip Pemasaran. Jilid 1. Erlangga. Jakarta.

Kotler, Philip and Amstrong, Gary (2012).Priciples of Marketing Global 14thedition.New Jersey: Prentice.

Kotler, P and Kevin L Keller, (2012). Marketing Management. 14th Edition. Pearson, United States of America.

Londong, Dedy. (2012), Kepuasan konsumen, dilihat 15 Maret 2019, http://dedylondong.blogspot.com/2012/04/kepuasanpelanggancustomer.hml

Maryati. MC. (2014). Manajemen Perkantoran Efektif. Yogyakarta:UPP STIM YKPN.

Pramudyo, Anung. (2012). Pengaruh Citra Merek Terhadap Loyalitas Melalui Kepuasan Sebagai Intervening (Studi pada Mahasiswa Perguruan Tinggi Swasta di Yogyakarta). JBMA. Vol. 1, No. 1.

Thakur, Satendra. (2012). Brand Image, Customer Satisfaction and Loyalty Intantion: a study in the context of cosmetic product among the people of central india. Excel International Journal of Multidisciplinary Management Studies Vol. 2, No. 5.

Tjiptono, F. (2008). Strategi Bisnis Pemasaran. Andi. Yogyakarta. 